\title{
Heavy Metals in Soil and Vegetables Irrigated with Ex- Tin Mining Ponds Water in Barkin - Ladi Local Government Area Plateau State, Nigeria
}

\author{
Mafuyai G. M. ${ }^{\circledR}$ \\ Eneji I. S. ${ }^{2}$ \\ Sha'Ato R. ${ }^{3}$ \\ Nnamonu L. A. ${ }^{4}$
}

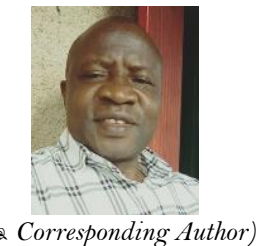

'Department of Chemistry, Faculty of Natural Sciences, University of Jos, Plateau State, Nigeria. Email: godwinmafoo2@gmail.com

${ }_{2,3,4}$ Department of Chemistry, College of Science, University of Agriculture, Makurdi Benue State, Nigeria.

\section{Abstract}

Tin mining pond water irrigated fields can cause potential contamination with heavy metals to soil and vegetables, thus pose a threat to human beings. The current study was designed to investigate the contamination of the soil with toxic heavy metals and their accumulation in edible vegetable crops. The heavy metals $\mathrm{Pb}, \mathrm{Cu}, \mathrm{Cd}, \mathrm{Zn}, \mathrm{Cr}, \mathrm{Fe}, \mathrm{Mn}$ and $\mathrm{As}$ were analyzed for their bioaccumulation factors to provide baseline data regarding environmental safety and the suitability of tin mining pond water for irrigation in the future. The contamination factor $(\mathrm{CF})$ of these metals in the soil were calculated and indicated levels of metal contamination in the order of $\mathrm{Cd}>\mathrm{Zn}>\mathrm{Pb}>\mathrm{Cr}>\mathrm{Cu}>\mathrm{As}>\mathrm{Fe}>\mathrm{Mn}$. The concentrations of $\mathrm{Pb}, \mathrm{Cd}, \mathrm{Cr}$, As, and $\mathrm{Mn}$ in the edible vegetables were above the safe limit prescribe by FAO/WHO, 2007 and EU, 2002 in all studied vegetables. The results indicated a potential pathway of human exposure to slow poisoning by heavy metals due to the utilization of vegetables grown on heavy metal contaminated soil that was irrigated with tin mining pond water sources. Amongst the studied vegetables, As and $\mathrm{Cr}$ were observed to exceeds tolerable limit. The irrigation source was identified as the source of the soil pollution in this study. Thus, their consumption might pose substantial health risk to consumers and therefore need for proper remediation to reduce health risk and the extent of heavy metals contamination.

Citation | Mafuyai G. M.; Eneji I. S.; Sha'Ato R.; Nnamonu L. A. (2019). Heavy Metals in Soil and Vegetables Irrigated with Ex- Tin Mining Ponds Water in Barkin - Ladi Local Government Area Plateau State, Nigeria. Agriculture and Food Sciences Research, 6(2): 211-220.

\section{History:}

Received: 15 July 2019

Revised: 19 August 2019

Accepted: 24 September 2019

Published: 31 October 2019

Licensed: This work is licensed under a Creative Commons Attribution 3.0 License (cc)

Publisher: Asian Online Journal Publishing Group
Acknowledgement: I give God Almighty the glory for sustaining my soul with nourishment to end this research work. There are assured people whom without their support we would have great difficulties accomplishing this study. First, it has been a great benefit working with our supervisor Professor I. S. Eneji, whom without his guidance, support and fruitful comments and I. S. Enej, whom without his guidance, support and fruitul comments and discussion, this research would never have been completed. Special thanks are also extended to my wife for her support and prayers during the period. The
technical staff at the Chemistry Department, University of Jos, Nigeria, thank you all for your kind support and understanding may Lord bless you all. Funding: This study received no specific financial support. Competing Interests: The authors declare that they have no conflict of interests.

Transparency: The authors confirm that the manuscript is an honest, Transparency: The authors confirm that the manuscript is an honest,
accurate, and transparent account of the study was reported; that no vital features of the study have been omitted; and that any discrepancies from the features of the study have been omitte
study as planned have been explained.

Ethical: This study follows all ethical practices during writing.

\section{Contents}

1. Introduction 


\section{Contribution of this paper to the literature}

This study contributes to existing literature by providing a baseline research on heavy metals in ex-mining pond water accumulation in vegetables and the need for quotient.

\section{Introduction}

Mining of solid minerals has been identified as a major entry point of heavy metals into the environment consequently polluting various components of the environmental media [1]. Mining, which involves the extraction of naturally occurring minerals from the earth's crust, is considered the world's second oldest and most important industry after agriculture [2]. In the process of mining a particular metal the entire soil mass is excavated, laid bare and expose to the environmental agencies of weathering, degradation and transportation, this result in soil erosion and extensive contamination of the surrounding areas. The abandoned ponds and dumps tailing scattered still impact the environment by contaminating vegetables as well as pollution of underground water by discharged leachate [3].

Heavy metals are considered as one among the most important environmental concerns because of their toxicity and accumulation in body $[4],[5],[6]$. Heavy metals are those metals which have a specific density of more than $5 \mathrm{~g} / \mathrm{cm} 3$ and harmfully affect the living organisms as well as environment and living organisms [7]. These metals are essential to maintain the normal body physiology and functioning when present in very low concentrations. However, they become lethal when certain threshold levels exceed. Many studies have been conducted throughout the world in relation to plants and soil pollution with heavy metals through irrigation by urban and industrial effluents [8]. Vegetables are important components of a healthy and perfect diet of human beings [9].

In a developing like country like Nigeria, the fight against poverty, hunger, malnutrition and undernourishment continues to be a basic goal of development and a variety of strategies are being applied based on micronutrient rich food like vegetables considered essential. These Vegetables are the fresh and edible portions of herbaceous plants. They are very popular in Nigeria, though, its production is low in rainy season compared to dry season due to differences in environmental conditions, non-availability of high yielding varieties and cultural practices in the crop production [10]. They are important class of food substances highly beneficial for the maintenance of health and prevention of diseases [11].

The inclusion of vegetables in human diets has been identified as a major means of promoting balanced diets across populations of various income brackets [12]. This is because green vegetables have been recognized as one of the richest natural sources of essential minerals, protein and vitamins. In addition to being cheap sources of macro and micronutrients, vegetables could also be efficiently produced with limited resources. The regular consumption of vegetables, specifically the dark green leafy vegetables is highly recommended because of their potential in reducing the risks of chronic diseases [13], [14].

Mining generally enriched heavy metals in soil leading to elevated levels in both plants and water samples [15]. Sometimes the metals are very well preserved for hundreds of years and can remain a potential hazard for the environment. Heavy metals are currently of environmental concern due to their bioaccumulation in soil and vegetables [16]. The soil, water and vegetable resulting from mining operations contain potentially carcinogenic levels of heavy metals and these elements could be related to the high prevalence of upper gastrointestinal cancer rates in the in the country [13]. The determination of heavy metal distribution in plants and environmental media is one of the most accurate criteria related to environmental pollution [17]. The accumulation of heavy metals in agricultural soils is of increasing concern because of food safety, potential health risks, and its detrimental effects on soil ecosystems [18],[19]. The accumulation of heavy metals in cultivated plants due to environmental media, fertilizers, and pesticides have a negative effect on plant growth and human health. The concentrations in plants can affect humans directly either through ingestion or through the food web by ingestion of crops or animals or indirectly-damaging environmental health [20]. The environmental exposure to heavy metals is a well-known risk factor for cancer [13]. Some metal ions like cadmium, lead and, chromium have toxic effects on biochemical reactions in our body. Heavy metals can be harmful due to their potential accumulation in different tissues of humans. Even in low concentrations, heavy metals have detrimental health effects, because they are nonbiodegradable and persistent in nature [21],[17]. The health risks of heavy metals through consumption of vegetables from these mining soils are of great concern in the study area.

Irrigation has contributed significantly to poverty alleviation, food security, and improving the quality of life for rural populations. However, the sustainability of irrigated agriculture is being questioned, both economically and environmentally. The increased dependence on irrigation has not been without its negative environmental effects. Thus, the need to investigate the levels of accumulation of heavy metal concentrations in the edible parts of some cultivated vegetables irrigated with Ex - Tin Mining water in the area.

\section{Materials and Methods}

\subsection{Study Area}

The study was carried out in Barkin - Ldai Local Government Areas of Plateau State Figure 1. The study areas lie between latitude $9^{\circ} 30^{\prime} 40^{\prime \prime} \mathrm{N}$ to $9^{\circ} 33^{\prime} 20^{\prime \prime}$ and longitude $8^{\circ} 53^{\prime} 20^{\prime \prime} \mathrm{E}$ to $8^{\circ} 54 \prime 40^{\prime \prime} \mathrm{E}$. The study area played host to a lot of mining activities by foreign companies which rendered the area derelict with numerous waste dumps and ponds. Soil and vegetables samples were collected through stratified random sampling method from four different farms each irrigated with tin mining ponds pond water. $1 \mathrm{~kg}$ of each of the vegetable samples including carrot, cabbage, garden egg, spinach, pepper and tomato from each stratum was collected. Three replications of each of these samples were analyzed for their heavy metals concentration using Flame Atomic Absorption Spectroscopy (FAAS). 


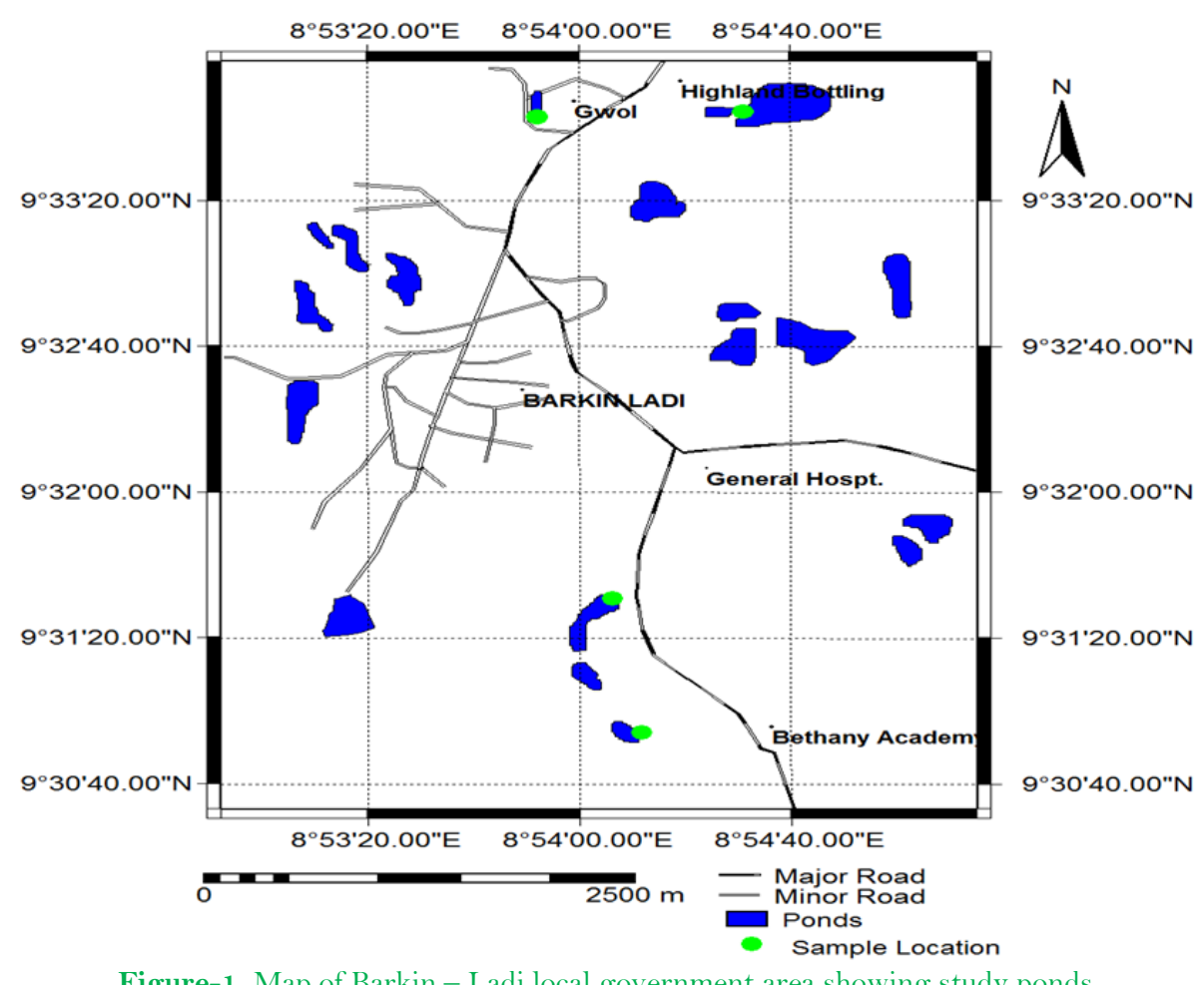

Figure-1. Map of Barkin - Ladi local government area showing study ponds.

\subsection{Soil Sampling and Preparation}

Soil samples were obtained from four farms each irrigated with tin mining pond water in the study farms viz: $\mathrm{B}_{1}=$ Opp. Bethany Acad. $\mathrm{B}_{2}=$ Hosp. Raod, $\mathrm{B}_{3}=$ Gwol, $\mathrm{B}_{4}=$ Behind Highland Bottling Company. The soil samples was collected at depth ranging between $0-20 \mathrm{~cm}$ using a steel soil auger and kept in tagged polythene bags. The soil samples were air-dried and sieved to $<0.25 \mathrm{~mm}$, then stored in desiccators prior to analysis of heavy metals. $5 \mathrm{~g}$ of dried and sieved subsoil sample was taken into $100 \mathrm{~mL}$ of conical flask. $20 \mathrm{~mL}$ of $1: 1 \mathrm{HNO}_{3}$ was added to conical flask and covered with a watch glass. Then the sample was evaporated to 5 to $8 \mathrm{~mL}$ on a hot plate. After cooling, 5 to $10 \mathrm{~mL}$ of $\mathrm{HClO}_{4}$ and $20 \mathrm{~mL}$ of metal-free distilled water added. Then the sample was again evaporated to 10 to $12 \mathrm{~mL}$ on the hot plate. After cooling, the sample was filtered through Whatman No. 42 filter paper and the filtrate transferred to a $100 \mathrm{~mL}$ volumetric flask and make up to mark with metal-free distilled water [22]. The concentrations of $\mathrm{Pb}, \mathrm{Cr}, \mathrm{Cu}, \mathrm{Cd}, \mathrm{Zn}, \mathrm{Mn}$ and As were be determined by Atomic Absorption Spectrophotometer (FAAS. PG990).

\subsection{Contamination Factor (CF)}

The contamination factor was determined to express the level of metal contamination in surface soil and vegetables. The contaminant factor is calculated using the following formula:

$$
C F=\frac{\text { Cmetal }}{\text { Cbackground }}
$$

where: $\mathrm{C}_{\text {Metal }}$ is the concentration of a given metal in the soil and $\mathrm{C}_{\text {Background }}$ is a metal concentration of a control soil sample. The $\mathrm{CF}$ value for describing the contamination levels is summarized in Table 1.

Table-1. Level of contaminant based on $(\mathrm{CF})$ values.

\begin{tabular}{c|l}
\hline CF values & Contamination remark \\
\hline$<1$ & No contamination \\
\hline $1-2$ & Suspected contamination \\
\hline $2-3.5$ & Slight contamination \\
\hline $3.5-8.0$ & Moderate contamination \\
\hline$>0-27$ & Severe contamination \\
\hline$>27$ & Extreme contamination \\
\hline
\end{tabular}

\subsection{Collection and Preparation of Vegetables for Analysis}

The following vegetables were collected and analysed during dry and rainy season: Carrot (Daucus carota subsp. Sativus), family: Apiaceae; Spinach (Spinacia oleracea L.), family: Amaranthaceae and Tomato (Lycopersicon Esculatum L.), family: Solanaceae, cabbage (Brassica oleracea), red pepper (Capsicum anum) and Garden Egg (Solanum melongena), respectively. The vegetables (mature) samples were collected randomly from the both farms treated. Healthy vegetables were collected carefully and washed thoroughly with tap water followed by distilled water and thereafter, kept on refrigerated under suitable condition analysis. The vegetables were cut into pieces with a stainless knife and dried at laboratory temperature and then powdered with mortar pestle before digestion to determine the heavy metals concentrations.

\subsection{Plant Samples Digestion for Metal Analyses}

One gram of each milled homogenized sample were weighed using a digital weighing balance into a conical flask. Exactly $5 \mathrm{~mL}$ of $60 \%$ hydrochloric acid $(\mathrm{HCl})$ and $10 \mathrm{~mL}$ of $70 \%$ nitric acid $\left(\mathrm{HNO}_{3}\right)$ was added into the weighed samples. The sample mixture was digested with moderate heat $\left(50^{\circ} \mathrm{C}\right)$ on a hot-plate until white fumes evolved, making it brownish solution. The heat was intensified further for few minutes to expel off most of the hydrochloric acid $(\mathrm{HCl})$. Exactly $50 \mathrm{~mL}$ of distilled water was added into the solution and heated for a few minutes, 
allowed to cool before being filtered through Whatman No. 42 paper $(11 \mu \mathrm{m})$ into a dispensed transparent plastic container that is clean with detergent and treated successively with $\mathrm{HCl}$ and rinsed with deionized water. The filtered sample was left to stand for few minutes for the aspiration of the element. The digested samples was then analyzed for the concentrations of; lead $(\mathrm{Pb})$, manganese $(\mathrm{Mn})$, chromium $(\mathrm{Cr})$, cadmium $(\mathrm{Cd})$, zinc $(\mathrm{Zn})$, cupper $(\mathrm{Cu})$, iron $(\mathrm{Fe})$ and arsenic $(\mathrm{As})$ using Atomic Absorption Spectrophotometer (AAS).

\subsection{Statistical Analysis}

Descriptive statistics viz., mean, standard error, standard deviation, minimum and maximum values of parameters are measured.

\subsection{Karl Pearson's Coefficient of Correlation}

Coefficient of correlation ( $r$ ) is a quantitative measure of the correlation between two variables. The correlation coefficient is measure of correlation is based on arithmetic mean and standard deviation. This method can be used to measure correlation for individual series as well as for grouped data. The following equation is used for getting Pearson's coefficient $(r)$ is:

$$
r=\sum \frac{(\bar{X}-X)(\bar{Y}-Y)}{n S x S y}
$$

where, $\quad r=$ coefficient of correlation, $X=$ variable $X, \bar{X}=$ mean of variable $X$.

$\mathrm{Y}=$ variable $\mathrm{Y}, \mathrm{Y}=$ mean of variable $\mathrm{Y}, \mathrm{n}=$ number of pairs of variables.

$\mathrm{Sx}=\mathrm{SD}$ of variable $\mathrm{X}$, and $\mathrm{Sy}=\mathrm{SD}$ of variable $\mathrm{Y}$.

\section{Results and Discussion}

\subsection{Heary Metals in Soil}

Heavy metals in the soil are derived from natural components or geological sources as well as from human activities or anthropogenic sources. Normally heavy metals in soil are found in several forms. These forms are involved in their movement from soil to plant. The conversion of immobile or non-bioavailable forms of heavy metals to mobile or bioavailable forms is dynamic phenomenon in the soil and occurring continually is regulated by physical, chemical and biological processes and interactions between them. As a result it is found that any form is not stable for long time. In this study total content of soil $\mathrm{Pb}, \mathrm{Cu}, \mathrm{Cd}, \mathrm{Zn}, \mathrm{Cr}, \mathrm{Fe}, \mathrm{Mn}$ and As are considered which are depicted in

Lead $(\mathbf{P b})$ : The mean concentration of $\mathrm{Pb}$ was $67.9 \pm 8.2 \mathrm{mg} / \mathrm{Kg}$ for the four different farm soil irrigated with tin mining pond. The highest concentration of $80.6 \mathrm{mg} / \mathrm{Kg}$ was observed in farm $\mathrm{B}_{2}$ with the lowest $59.2 \mathrm{mg} / \mathrm{Kg}$ in farm $B_{1}$. The trend of the concentrations in the four different farms was $B_{2}>B_{3}>B_{2}>B_{4}>B_{1}$. This result showed similar trend of increased in $\mathrm{Pb}$ concentration in the soil irrigated with tin mining pond water. It was observed that $\mathrm{Pb}$ is positively correlated with $\mathrm{Zn}$ in dry season and negatively with $\mathrm{Cu}, \mathrm{Cr}$ and $\mathrm{Fe}$ while in rainy season $\mathrm{Pb}$ is positively correlated with $\mathrm{Fe}$. The reported values are within he prescribed safe limit of irrigation soil [24] standard limits. The value of $\mathrm{Pb}$ obtained in this work is higher compared with that reported in Kassa Ropp Barkin - Ladi [25]. Similar work done revealed Pb concentration in soil to range from $1-58 \mathrm{mg} / \mathrm{Kg}$ Mahmood and Malik [26]. Ratul, et al. [27] reported $28.13 \mathrm{mg} / \mathrm{Kg}$ in agricultural soil irrigated with contaminated river water lower than the concentration reported in this study.

$\mathrm{Pb}$ in soil treated with mining pond water is positively correlated with $\mathrm{Mn}$ and As in dry season and rainy season but a significant positive correlation is showed between $\mathrm{Pb}$ and available phosphorus in the treated soil collected during rainy season. The study showed the significant difference $(\mathrm{p}<0.05)$ in the $\mathrm{Pb}$ content of the treated soils collected in both seasons. The Pb enrichment in the mining pond water irrigated soils as compared to ground water irrigated soils are collaborated with the findings of $15.4 \pm 6.6 \mathrm{mg} / \mathrm{Kg}$ and $9.31 \pm 2.2 \mathrm{mg} / \mathrm{Kg}$ $[26],[28]$.

Copper $(\mathbf{C u})$ : The mean value of $\mathrm{Cu}$ in mining pond water treated soil collected was $20.3 \mathrm{mg} / \mathrm{Kg}$ and the highest value of $27.2 \mathrm{mg} / \mathrm{Kg}$ was obtained in farm $\mathrm{B}_{1}$ with the lowest $15.6 \mathrm{mg} / \mathrm{Kg}$ at farm $\mathrm{B}_{2}$. This result is lower compared to the findings $42.0-111.6 \mathrm{mg} / \mathrm{Kg}$ reported [3] which recorded extremely high concentrations of copper at industrial sites, and the also the reported $69.01 \mathrm{mg} / \mathrm{Kg}$ in agricultural soil irrigated with contaminated river water [27]. The $\mathrm{Cu}$ concentration of the soil irrigated with tin mining pond water is within the safe limit for cultivation [24]. The trend of $\mathrm{Cu}$ in the soil sample farms is in the order of $\mathrm{B}_{1}>\mathrm{B}_{4}>\mathrm{B}_{3}>\mathrm{B}_{2}$, respectively. The metals contents in both soil irrigation with mining pond water also corroborated with the findings of Henry, et al. [29],Singh, et al. [5].

Cadmium (Cd): The concentration of $\mathrm{Cd}$ in the mining pond water treated soil with tin mining pond water in both sites studied shows a mean of $0.94 \pm 0.4 \mathrm{mg} / \mathrm{Kg}$. The highest concentration was obtained in farm $\mathrm{B}_{1} 1.17$ $\mathrm{mg} / \mathrm{Kg}$ and the lowest $0.28 \mathrm{mg} / \mathrm{Kg}$ at $\mathrm{B}_{4}$. The concentration obtained in this work for soil treated with tin mining pond water agrees with the $0.965 \mathrm{mg} / \mathrm{Kg}$ reported [27] in agricultural soil irrigated with contaminated river water. Comparing with the safe limit of $\mathrm{Cd}$ in the soil it is found that both farm soils are within the prescribed standards of $3.0 \mathrm{mg} / \mathrm{Kg}$ set [30],[31]. Cadmium concentration in soil was relatively high, this may be attributed to applications of fertilizers and other farming practices including used of pesticides. Generally, the high concentrations of metals in this area could also be as a result of the tin mine activities, wastes dumped and metals availability in the earth crust.

The treated soil does not show any significant correlation with other parameter at the significant difference $(\mathrm{p}$ $<0.05$ ). In this study $\mathrm{Cd}$ concentration in both tin mining pond water irrigated farm soils are lower compared to the literature values reports of $15.38 \pm 6.6 \mathrm{mg} / \mathrm{Kg}, 3.54 \pm 0.6 \mathrm{mg} / \mathrm{Kg}$ and $9.91 \pm 1.1 \mathrm{mg} / \mathrm{Kg}[26],[25],[32]$ respectively.

Zinc $(\mathbf{Z n})$ : The mean concentration of $\mathrm{Zn}$ in the mining pond water treated farm was $68.87 \pm 18.4 \mathrm{mg} / \mathrm{Kg}$. The highest concentration obtained was in farm $\mathrm{B}_{2}$ soil $94.8 \mathrm{mg} / \mathrm{Kg}$ and lowest at $\mathrm{B}_{3}$ soil $54.3 \mathrm{mg} / \mathrm{Kg}$. From the 
concentration of $\mathrm{Zn}$ obtained in the soil irrigated with tin mining pond water, it is clear that the water has potential for the development of $\mathrm{Zn}$ enrichment. Both the soil samples analyzed has been found to be enriched with more $\mathrm{Zn}$. The $\mathrm{Zn}$ concentration in both studied farm soils is within the safe limit of $200 \mathrm{mg} / \mathrm{Kg}$ prescribed [31]. The $\mathrm{Zn}$ concentration in the wastewater irrigated soil reported in this study is in agreement with wastewater irrigated soil concentrations of $50.80 \pm 28.6 \mathrm{mg} / \mathrm{Kg}$ published [26] and reported concentration of $45.73 \mathrm{mg} / \mathrm{Kg}$ [27] in agricultural soil irrigated with contaminated river water; but however, higher compared to the result of $3.9 \pm 0.1$ and $6.03 \pm 1.7 \mathrm{mg} / \mathrm{Kg}$ reported [28].

Chromium (Cr): The soil samples that are collected has a mean $\mathrm{Cr}$ concentration in mining pond water treated soil as $12.5 \pm 4.1 \mathrm{mg} / \mathrm{Kg}$. It was observed that $\mathrm{Cr}$ in both farm soils, the highest concentration was found in farm $\mathrm{B}_{1}$ soil $14.5 \mathrm{mg} / \mathrm{Kg}$ and lowest in $\mathrm{B}_{2}$ soil $11.1 \mathrm{mg} / \mathrm{Kg}$. The result reported in this study is lower compared with $22.9 \mathrm{mg} / \mathrm{Kg}$ reported by and $20.01 \pm 11.3 \mathrm{mg} / \mathrm{Kg}[15]$, [26] and $54.2 \mathrm{mg} / \mathrm{Kg}$ reported in Kassa Ropp for similar tin mining soil and $69.75 \mathrm{mg} / \mathrm{Kg}$ reported by Daniel, et al. [25], Ratul, et al. [27] in agricultural soil irrigated with contaminated river water. However, the low value obtained may be as attributed to leaching of metals beneath the soil. The $\mathrm{Cr}$ concentration in soil of both plots irrespective are within the $150 \mathrm{mg} / \mathrm{Kg}$ safe limit standard [30].

The study also showed the significant difference $(\mathrm{p}<0.05)$ in the $\mathrm{Cr}$ content of treated soils collected in both seasons.

Iron $(\mathbf{F e})$ : The soil sample irrigated with tin mining pond water during at the various sampling farms has mean concentration of $491.48 \pm 28.5 \mathrm{mg} / \mathrm{Kg}$. Higher concentration of Fe were observed in the soil around farm $\mathrm{B}_{1}$ $526 \mathrm{mg} / \mathrm{Kg}$ and the lowest farm $\mathrm{B}_{2} 478 \mathrm{mg} / \mathrm{Kg}$ mining ponds, this may be as a result of the washing of mining piled dumps by runoff water during rainfalls. In the same vain Fe correlated negatively with $\mathrm{Mn}$ and As. The results show that iron $(\mathrm{Fe})$ is the most abundant essential metal in both soil and vegetable samples, samples. The trend of concentration of $\mathrm{Fe}$ in the farm soils analyzed is in the order of $\mathrm{B}_{1}>\mathrm{B}_{4}>\mathrm{B}_{3}>\mathrm{B}_{2}$. The variations in the absorption of $\mathrm{Fe}$ from the soil by the plant's tissues are evident in the low $\mathrm{Fe}$ contents in the vegetable samples. The high concentrations of Fe in the soil samples may suggest a very anthropogenic source of Fe, which allows the percolation of $\mathrm{Fe}$ to the soil depths rather the surfaces. Boamponisem reported $14.08 \mathrm{mg} / \mathrm{K}$ lower values of $\mathrm{Fe}$ as compared to this work [32].

Manganese (Mn): The soil irrigated with tin mining pond water in both farms showed a of $18.1 \pm 1.3 \mathrm{mg} / \mathrm{Kg}$, with the highest concentration obtained in farm $\mathrm{B}_{4}$ soil $19.8 \mathrm{mg} / \mathrm{Kg}$ and the lowest at $\mathrm{B}_{1}$ soil $16.3 \mathrm{mg} / \mathrm{Kg}$. The trend in concentration in the farms soil is in the order of $B_{4}>B_{3}>B_{2}>B_{1}$. This variation in concentration of Mn may be attributed to accumulation washing from different places such as roads, ashes from burn vegetation washed down by rainfall. The concentration of $\mathrm{Mn}$ reported in the soils studied is lower compared to limit of $80.0 \mathrm{mg} / \mathrm{Kg}$ prescribed by USEPA [31]. Increased Mn content in the mining pond water irrigated soils as compared with ground water irrigated soils agrees with findings of Mahmood and Malik [26].

Arsenic (As): The mean concentration of As in tin mining pond water treated soil collected from both farms was $146 \pm 23 \mathrm{mg} / \mathrm{Kg}$. The highest concentration was recorded in B3 soil $174 \mathrm{mg} / \mathrm{Kg}$ with the lowest obtained in $\mathrm{B} 1$ soil $114 \mathrm{mg} / \mathrm{Kg}$. The level of concentration of $\mathrm{As}$ in the farms is in the order of $\mathrm{B}_{3}>\mathrm{B}_{4}>\mathrm{B}_{2}>\mathrm{B}_{1}$. The concentration of As recorded in this work is higher compared to the mean total arsenic concentrations of $50-60$ $\mathrm{mg} / \mathrm{kg}$ recorded for agricultural soils treated with arsenical pesticides [33],[34]. The result shows that there is accumulation of As in the soil as a result industrial wastes and pesticide applications which might increase concentrations. The As level in the irrigated soils is within the safe limit for cultivation. As, show positive correlation with $\mathrm{Mn} \mathrm{Cr}$ and $\mathrm{Pb}$. Naturally elevated levels of arsenic in soils may be associated with geological substrata such as sulfide ores therefore, anthropogenic contaminated soils can have several concentrations of arsenic. Arsenic concentrations of up to $27000 \mathrm{mg} / \mathrm{kg}$ were reported in soils contaminated with mine or smelter wastes [35]. Soil on agricultural land treated with arsenical pesticides may retain substantial amounts of arsenic [34].

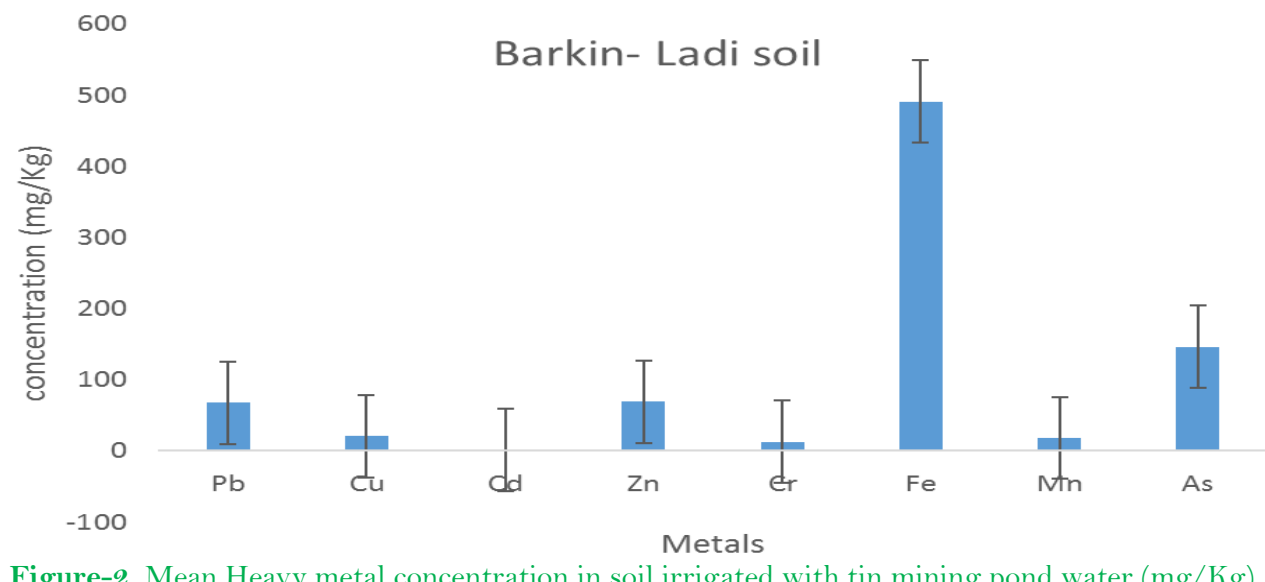

Table-2. Contamination of heavy metals for soil at different irrigated soil

\begin{tabular}{c|c|c|c|c}
\hline Metals & Bethany academy $\left(\mathbf{B}_{\mathbf{1}}\right)$ & Hospital road $\left(\mathbf{B}_{2}\right)$ & Gwol $\left(\mathbf{B}_{\boldsymbol{s}}\right)$ & Highland bottling company $\left(\mathbf{B}_{4}\right)$ \\
\hline $\mathrm{Pb}$ & 1.26 & 2.25 & 2.37 & 1.32 \\
\hline $\mathrm{Cu}$ & 0.69 & 1.67 & 1.32 & 1.27 \\
\hline $\mathrm{Cd}$ & 3.53 & 3.39 & 4.15 & 3.84 \\
\hline $\mathrm{Zn}$ & 1.08 & 2.14 & 2.18 & 1.37 \\
\hline $\mathrm{Cr}$ & 1.52 & 2.93 & 2.35 & 1.09 \\
\hline $\mathrm{Fe}$ & 1.39 & 1.26 & 1.38 & 1.14 \\
\hline $\mathrm{Mn}$ & 1.33 & 0.30 & 1.36 & 0.99 \\
\hline $\mathrm{As}$ & 1.02 & 1.31 & 1.22 & 1.33 \\
\hline
\end{tabular}




\subsection{Contamination Factor (CF) of Heary Metals in Soil}

Contamination factor (EF) of heavy metals in the soil was calculated with help of the formula provided [36]. Soils collected from the cultivated soils' shows variation in metal concentration. Soils collected from the various farms of the study sites shows sequence of contamination in descending order as:

$$
\mathrm{Cd}>\mathrm{Zn}>\mathrm{Pb}>\mathrm{Cr}>\mathrm{Cu}>\mathrm{As}>\mathrm{Fe}>\mathrm{Mn} \text {. }
$$

Based on the contamination categories as proposed [23] it is found that soils irrigated with tin mining pond water were suspected to contamination with $\mathrm{Cr}, \mathrm{Pb}$, and $\mathrm{Zn}$. The rest of the metals exhibit the minimal deficiency of mineral contamination in the soil and slight contamination was observed in the soil with $\mathrm{Cd}$ in all farms studied.

According [37] contamination values between 0.5 and 1.5 indicate the metal is entirely from the crust materials or natural processes, whereas contamination values greater than 1.5 suggest that the sources are more likely to be anthropogenic. Higher transfer coefficients reflect high soil contents or greater potentials of plants to absorb metals and bio-accumulate into tissues [38]. However, low transfer coefficients have been reported to indicate strong sorption of the metals to soil colloids [39]. Contamination factor ( $\mathrm{CF})$ of heavy metals in the irrigated soils is also highlighted as $\mathrm{Cd}(2.46)>\mathrm{Cr}(2.43)>\mathrm{Zn}(1.67)>\mathrm{Cu}(1.36)>\mathrm{Pb}(1.31)[40]$.

Table-3. Mean \pm SD concentration of heavy metals in vegetables $(\mathrm{mg} / \mathrm{Kg})$

\begin{tabular}{c|c|c|c|c|c|c}
\hline \multirow{2}{*}{ Metals } & \multicolumn{7}{|c}{ Vegetables } \\
\cline { 2 - 7 } & Tomatoes & Garden egg & Pepper & Cabbage & Carrot & Spinach \\
\hline $\mathrm{Pb}$ & $0.491 \pm 0.11$ & $0.396 \pm 0.05$ & $0.307 \pm 0.26$ & $0.164 \pm 0.03$ & $0.465 \pm 0.02$ & $0.455 \pm 0.04$ \\
\hline $\mathrm{Cu}$ & $0.071 \pm 0.01$ & $0.076 \pm 0.01$ & $0.065 \pm 0.00$ & $0.065 \pm 0.01$ & $0.090 \pm 0.01$ & $0.062 \pm 0.01$ \\
\hline $\mathrm{Cd}$ & $0.009 \pm 0.00$ & $0.006 \pm 0.01$ & $0.006 \pm 0.00$ & $0.005 \pm 0.00$ & $0.022 \pm 0.01$ & $0.014 \pm 0.01$ \\
\hline $\mathrm{Zn}$ & $0.376 \pm 0.04$ & $1.104 \pm 0.08$ & $0.395 \pm 0.02$ & $0.184 \pm 0.02$ & $0.913 \pm 0.06$ & $0.448 \pm 0.03$ \\
\hline $\mathrm{Cr}$ & $0.154 \pm 0.03$ & $0.116 \pm 0.00$ & $0.106 \pm 0.01$ & $0.109 \pm 0.01$ & $0.148 \pm 0.02$ & $0.147 \pm 0.03$ \\
\hline $\mathrm{Fe}$ & $1.551 \pm 0.21$ & $1.170 \pm 0.02$ & $1.489 \pm 0.03$ & $1.489 \pm 0.07$ & $1.647 \pm 0.14$ & $1.554 \pm 0.21$ \\
\hline $\mathrm{Mn}$ & $0.454 \pm 0.39$ & $0.825 \pm 0.11$ & $0.177 \pm 0.01$ & $0.166 \pm 0.01$ & $0.791 \pm 0.15$ & $0.115 \pm 0.01$ \\
\hline $\mathrm{As}$ & $0.076 \pm 0.01$ & $0.043 \pm 0.01$ & $0.033 \pm 0.02$ & $0.028 \pm 0.01$ & $0.466 \pm 0.39$ & $0.046 \pm 0.00$ \\
\hline
\end{tabular}

\subsection{Heavy Metals Accumulation in Cultivated Vegetables}

Tomato: The result shows that $\mathrm{Pb}$ concentration in tomatoes is $0.49 \pm 0.1 \mathrm{mg} / \mathrm{Kg}$. The values obtained are similar to the value $0.26-0.70 \mathrm{mg} / \mathrm{Kg}$ Mahmood and Malik [26] and $1.15 \pm 0.29 \mathrm{mg} / \mathrm{K}$ reported values [41] ; in a research on the level of $\mathrm{As}, \mathrm{Cd}, \mathrm{Cr}, \mathrm{Hg}$ and $\mathrm{Pb}$ in soil and some vegetables which showed concentrations above maximum permissible limit and standard value. It also observed high levels of $\mathrm{Pb}(2.40 \pm 0.99) \mathrm{mg} / \mathrm{Kg}$ and $\mathrm{Cd}$ $(0.25 \pm 0.11) \mathrm{mg} / \mathrm{Kg}$ in wastewater irrigated tomatoes in Egypt [42]. Higher concentration of $10.75 \mathrm{mg} / \mathrm{Kg}$ are also reported in wastewater irrigated tomatoes [43].

The mean concentration of Arsenic was $0.076 \mathrm{mg} / \mathrm{Kg}$. This concentration is high compared to $0.06 \pm 0.02$ $\mathrm{mg} / \mathrm{Kg}$ reported [44] and $0.62 \pm 0.19 \mathrm{mg} / \mathrm{Kg}$ [41]. The high value of Arsenic in might be due the usage of arsenic containing chemicals such as pesticides and herbicides (calcium arsenate, cupper acetoarsenate and lead hydrogen arsenate). It was reported that these were used in pig and poultry feeds which in turn introduce arsenic into the soil and plants as chicken dug is used as fertilizers [45].

The $\mathrm{Cr}$ concentrations were also high in the study areas, with a mean of $0.15 \mathrm{mg} / \mathrm{Kg}$. The concentration of $\mathrm{Cr}$ obtained in this study is lower compared to $0.66 \mathrm{mg} / \mathrm{Kg}$ reported in similar studies $[46],[47]$.

$\mathrm{Mn}$ has a mean concentration of $0.45 \pm 0.39 \mathrm{mg} / \mathrm{Kg}$ in the tomatoes cultivated with tin mining pond water in the various farms studied. However, the might have been due washing by runoff water from the immediate vicinity since several anthropogenic processes took place and tin mining is still occurring in small scale by illegal miners. This is agree with the $0.12 \mathrm{mg} / \mathrm{L}$ reported on the study of vegetables in Southern Turkey [48]. The high concentrations of some of these metal in the areas could be as a result of the closeness of the mining ponds to major traffic highways. Other metals such $\mathrm{Cu}, \mathrm{Zn}$, and $\mathrm{Fe}$, has concentrations of $0.071 \pm 0.01,0.376 \pm 0.04$ and 1.55 \pm 0.21 , respectively.

\begin{tabular}{c|c|c|c|c|c|c|c|c}
\multicolumn{7}{c}{ Table-4. Pearson's correlation coefficient matrix (Mean) concentration of heavy metals in tomatoes. } \\
\hline & $\mathbf{P b}$ & $\mathbf{C u}$ & $\mathbf{C d}$ & $\mathbf{Z n}$ & $\mathbf{C r}$ & $\mathbf{F e}$ & $\mathbf{M n}$ & $\mathbf{A s}$ \\
\hline $\mathrm{Pb}$ & 1.000 & & & & & & & \\
\hline $\mathrm{Cu}$ & -0.750 & 1.000 & & & & & & \\
\hline $\mathrm{Cd}$ & 0.743 & -1.000 & 1.000 & & & & & \\
\hline $\mathrm{Zn}$ & 0.906 & -0.399 & 0.389 & 1.000 & & & & \\
\hline $\mathrm{Cr}$ & -0.667 & 0.993 & -0.994 & -0.288 & 1.000 & & & \\
\hline $\mathrm{Fe}$ & -0.410 & 0.911 & -0.915 & 0.015 & 0.953 & 1.000 & & \\
\hline $\mathrm{Mn}$ & 0.869 & -0.325 & 0.315 & 0.997 & -0.211 & 0.095 & 1.000 & \\
\hline $\mathrm{As}$ & 0.365 & -0.890 & 0.894 & -0.064 & -0.937 & -0.999 & -0.143 & 1.000 \\
\hline
\end{tabular}

Statistically (p-value $<0.05$ ). $\mathrm{Pb}$ is positively correlated with $\mathrm{Cd}$, $\mathrm{Zn}$ and $\mathrm{Mn}$ while $\mathrm{Zn}$ with $\mathrm{Mn}$. A positively correlation was also notice between $\mathrm{Cd}$ and $\mathrm{As}$, and also $\mathrm{Cr}$ is negatively correlated with $\mathrm{Cd}$ and As. The order of metal concentration in tomatoes in this work is; $\mathrm{Fe}>\mathrm{Mn}>\mathrm{Zn}>\mathrm{Pb}>\mathrm{Cu}>\mathrm{Cr}>\mathrm{As}>\mathrm{Cd}$. Heavy metal accumulation in tomato due to long-term wastewater irrigation was also highlighted [29], [43], [49].

Garden egg: The mean concentrations of each heavy metals in the three farms shows that $\mathrm{Pb} 0.40 \pm 0.05, \mathrm{Cr}$ $(0.12 \pm 0.00)$ and $\mathrm{Mn}(1.17 \pm 0.02)$ As $(0.83 \pm 0.11) \mathrm{mg} / \mathrm{Kg}$ were higher than the standard permissible limit [50] respectively. The concentration of $\mathrm{Cu} 0.076 \pm 0.01$ below the permissible standard value of $0.7 \mathrm{mg} / \mathrm{Kg}$ in both garden egg irrigated with tin mining pond water while the concentration $\mathrm{Fe}$ and $\mathrm{Cd}$ are lower compared to other metals standards. The order of heavy metals accumulation in garden egg was $\mathrm{Fe}>\mathrm{Mn}>\mathrm{Pb}>\mathrm{Zn}>\mathrm{Cu}>\mathrm{Cr}>\mathrm{As}$ $>\mathrm{Cd}$. Pearson's correlation shows that in garden egg $\mathrm{Pb}$ is positively correlated with $\mathrm{Zn}$ and $\mathrm{Mn}$, while $\mathrm{Cu}$ is positively correlated with $\mathrm{Cr}$, and $\mathrm{Cd}$ negatively correlated with $\mathrm{Cr}$. The results obtained in this study were 
similar to the reported studies many scholars [43],[51],[52] who also reported high levels of $\mathrm{Zn}(3.91)$ and $\mathrm{Cd}$ (1.56) $\mathrm{mg} / \mathrm{Kg}$ in wastewater irrigated garden egg in Kaduna, Nigeria.

\begin{tabular}{c|c|c|c|c|c|c|c|c}
\multicolumn{6}{c}{ Table-5. Pearson's correlation coefficient matrix (Mean) concentration of heavy metals in garden egg. } \\
\hline & $\mathbf{P b}$ & $\mathbf{C u}$ & $\mathbf{C d}$ & $\mathbf{Z n}$ & $\mathbf{C r}$ & $\mathbf{F e}$ & $\mathbf{M n}$ & $\mathbf{A s}$ \\
\hline $\mathrm{Pb}$ & 1.000 & & & & & & & \\
\hline $\mathrm{Cu}$ & -0.750 & 1.000 & & & & & & \\
\hline $\mathrm{Cd}$ & 0.743 & -1.000 & 1.000 & & & & & \\
\hline $\mathrm{Zn}$ & 0.906 & -0.399 & 0.389 & 1.000 & & & & \\
\hline $\mathrm{Cr}$ & -0.667 & 0.993 & -0.994 & -0.288 & 1.000 & & & \\
\hline $\mathrm{Fe}$ & -0.410 & 0.911 & -0.915 & 0.015 & 0.953 & 1.000 & & \\
\hline $\mathrm{Mn}$ & 0.869 & -0.325 & 0.315 & 0.997 & -0.211 & 0.095 & 1.000 & \\
\hline $\mathrm{As}$ & 0.365 & -0.890 & 0.894 & -0.064 & -0.937 & -0.999 & -0.143 & 1.000 \\
\hline
\end{tabular}

Pepper: The mean concentration of the various heavy metals in pepper irrigated with tin mining pond water was $\mathrm{Pb}(0.307 \pm 0.26), \mathrm{Cu}(0.065 \pm 0.00), \mathrm{Cd}(0.006 \pm 0.00), \mathrm{Zn}(0.395 \pm 0.02) \mathrm{Cr}(0.106 \pm 0.01), \mathrm{Fe}(1.489 \pm 0.03), \mathrm{Mn}$ $(0.177 \pm 0.01)$ and As $(0.033 \pm 0.02)$. The concentration of $\mathrm{Cd}$ was slightly lower in all the study areas. The order of concentration of the heavy metals in pepper cultivated with tin mining pond water was $\mathrm{Fe}>\mathrm{Mn}>\mathrm{Pb}>\mathrm{Cu}>\mathrm{Zn}$ $>\mathrm{Cr}>\mathrm{As}>\mathrm{Cd}$. The concentrations of $\mathrm{Mn}, \mathrm{Cr}, \mathrm{Pb}$ and $\mathrm{Cd}$ in pepper in the studied areas have crossed the prescribed safe value [30],[50] respectively. The high concentration of this metals in pepper might be attributed to high level of pesticides and fertilizer on farmland for better yield of crops. Wastewater induced heavy metal accumulation in vegetables is also reported as $\mathrm{Mn}(19.1 \pm 1.7) \mathrm{mg} / \mathrm{Kg}$ accumulation in vegetables grown on farmlands irrigated with treated sewage water in Ghana [53]. $1.15 \pm 0.29 \mathrm{mg} / \mathrm{Kg}$ accumulation of $\mathrm{Cd}$ in pepper is also being reported [41]. $\mathrm{Pb}$ and $\mathrm{Cu}$ correlated positively $\mathrm{Cr}$, $\mathrm{Mn}$ and As, while $\mathrm{Cd}$ correlated positively with $\mathrm{Mn}$ and $\mathrm{As}$ and $\mathrm{Cr}$ negatively correlated with As. Heavy metals concentration in both sites vegetables showed significant level $(\mathrm{p}<0.05)$ accumulation except $\mathrm{Cd}(\mathrm{p}=0.05)$. Dorcas High levels of heavy metals are also reported vegetables irrigated with wastewater from mines and industrial discharges to soils $[54],[55],[56],[57]$.

\begin{tabular}{c|c|c|c|c|c|c|c|c}
\multicolumn{6}{c}{ Table-6. Pearson's correlation coefficient matrix (Mean) concentration of heavy metal in pepper $(\mathrm{mg} / \mathrm{kg})}$. \\
\hline & $\mathbf{P b}$ & $\mathbf{C u}$ & $\mathbf{C d}$ & $\mathbf{Z n}$ & $\mathbf{C r}$ & $\mathbf{F e}$ & $\mathbf{M n}$ & $\mathbf{A s}$ \\
\hline $\mathrm{Pb}$ & 1.000 & & & & & & & \\
\hline $\mathrm{Cu}$ & -0.751 & 1.000 & & & & & & \\
\hline $\mathrm{Cd}$ & 0.944 & 0.998 & 1.000 & & & & & \\
\hline $\mathrm{Zn}$ & -1.000 & -0.969 & -0.952 & 1.000 & & & & \\
\hline $\mathrm{Cr}$ & -0.873 & -0.707 & -0.664 & 0.861 & 1.000 & & & \\
\hline $\mathrm{Fe}$ & 0.763 & 0.910 & 0.933 & -0.779 & -0.351 & 1.000 & & \\
\hline $\mathrm{Mn}$ & 0.907 & 0.987 & 0.995 & -0.917 & -0.587 & 0.964 & 1.000 & \\
\hline $\mathrm{As}$ & 0.907 & 0.980 & 0.966 & -0.999 & -0.834 & 0.809 & 0.936 & 1.000 \\
\hline
\end{tabular}

Cabbage: The mean concentration of heavy metals in the studied cultivated cabbage irrigated with tin mining pond water was found to be $\mathrm{Pb}(0.164 \pm 0.03), \mathrm{Cu}(0.065 \pm 0.01), \mathrm{Cd}(0.01 \pm 0.00), \mathrm{Zn}(0.18 \pm 0.02), \mathrm{Cr}(0.11 \pm 0.01), \mathrm{Fe}$ (1.49 \pm 0.07$), \mathrm{Mn}(0.17 \pm 0.01)$ and As $(0.03 \pm 0.01) \mathrm{mg} / \mathrm{Kg}$. The concentration of metals in cabbage irrigated with tin mining pond water is lower compared to the reported literature of $0.22 \pm 0.2 \mathrm{mg} / \mathrm{Kg}$ and $6.25 \pm 1.2 \mathrm{mg} / \mathrm{Kg} 1.61 \pm 0.2$ $[56],[58],[59] \mathrm{mg} / \mathrm{Kg})$. Similar studies conducted show order of concentration of the heavy metals in is: $\mathrm{Fe}>$ $\mathrm{Mn}>\mathrm{Pb}>\mathrm{Zn}>\mathrm{Cr}>\mathrm{Cu}>\mathrm{As}>\mathrm{Cd}[29]$. It was therefore, noted that some of metals that are high in cabbage cross the standard permissible limits $\mathrm{FAO} / \mathrm{WHO}$.

The high levels of these metals in this vegetable might be as a result of the use of pesticides and herbicides and irrigated with tin mine water [60]. This also agrees with the findings that, the application of large volumes of partially treated or untreated wastewater in some parts of Africa has adversely affected both surface water bodies and the urban and peri-urban farmers using these water bodies as sources of irrigation [61]. The Pearson's correlation shows that $\mathrm{Pb}$ correlated positively with $\mathrm{Cu}, \mathrm{Mn}$, As, and negatively correlated $\mathrm{Cr}$. $\mathrm{Cd}$ is positively correlated with $\mathrm{Mn}$, As and negatively correlated with $\mathrm{Cr}$ at $(\mathrm{p}>0.05)$.

\begin{tabular}{c|c|c|c|c|c|c|c|c}
\multicolumn{6}{c}{ Table-7. Pearson's correlation coefficient matrix (Mean) concentration of heavy metals in cabbage. } \\
\hline & $\mathbf{P b}$ & $\mathbf{C u}$ & $\mathbf{C d}$ & $\mathbf{Z n}$ & $\mathbf{C r}$ & $\mathbf{F e}$ & $\mathbf{M n}$ & $\mathbf{A s}$ \\
\hline $\mathrm{Pb}$ & 1.000 & & & & & & & \\
\hline $\mathrm{Cu}$ & 0.993 & 1.000 & & & & & & \\
\hline $\mathrm{Cd}$ & -0.148 & -0.034 & 1.000 & & & & & \\
\hline $\mathrm{Zn}$ & 0.958 & 0.984 & 0.143 & 1.000 & & & & \\
\hline $\mathrm{Cr}$ & -0.754 & -0.824 & -0.538 & -0.911 & 1.000 & & & \\
\hline $\mathrm{Fe}$ & -0.994 & -0.974 & 0.260 & -0.919 & 0.674 & 1.000 & & \\
\hline $\mathrm{Mn}$ & 0.932 & 0.884 & -0.497 & 0.788 & -0.464 & -0.967 & 1.000 & \\
\hline $\mathrm{As}$ & 0.999 & 0.992 & -0.163 & 0.953 & -0.744 & -0.995 & 0.937 & 1.000 \\
\hline
\end{tabular}

Carrot: The heavy metals in the carrot analyzed from the sampled farms shows that the concentrations are higher in all studied metals. The metals studied crossed the safe limit of European Union (EU) [30]; FAO/WHO [50] limit with the exception of $\mathrm{Cu}, \mathrm{Zn}$, and $\mathrm{Fe}$ others were not safe for human consumption as their concentrations were above the maximum permissible limit, $0.30 \mathrm{mg} / \mathrm{kg}$. The mean concentrations of $\mathrm{Pb}(0.46$ $\mathrm{mg} / \mathrm{Kg})$ and As $(0.47 \mathrm{mg} / \mathrm{Kg})$ were higher compared to other toxic metals in carrot The studied metals are in order of their descending trend: $\mathrm{Fe}>\mathrm{Zn}>\mathrm{Mn}>\mathrm{As}>\mathrm{Pb}>\mathrm{Cr}>\mathrm{Cu}>\mathrm{Cd}$. studies showed that cadmium $(\mathrm{Cd}) \mathrm{had}$ mean concentration of $0.24 \mathrm{mg} / \mathrm{kg}$ in carrots in Barkin - Ladi Haipang compared [54] with the result of $0.02 \mathrm{mg} / \mathrm{Kg}$ recorded in this work. Several results have been reported of $\mathrm{Cd}$ in carrot due to irrigation with 
wastewater [26],[62],[63]. Pb correlated positively with $\mathrm{Cr}$ and negatively with $\mathrm{Mn}$. $\mathrm{Cd}$ and $\mathrm{Cr}$ showed negative correlation in significant level of $(\mathrm{p}<0.05)$.

Table-8. Pearson's correlation coefficient matrix (Mean) concentration of heavy metals in carrot.

\begin{tabular}{c|c|c|c|c|c|c|c|c}
\hline & $\mathbf{P b}$ & $\mathbf{C u}$ & $\mathbf{C d}$ & $\mathbf{Z n}$ & $\mathbf{C r}$ & $\mathbf{F e}$ & $\mathbf{M n}$ & As \\
\hline $\mathrm{Pb}$ & 1.000 & & & & & & & \\
\hline $\mathrm{Cu}$ & 0.993 & 1.000 & & & & & & \\
\hline $\mathrm{Cd}$ & -0.768 & -0.687 & 1.000 & & & & & \\
\hline $\mathrm{Zn}$ & 0.662 & 0.569 & -0.989 & 1.000 & & & & \\
\hline $\mathrm{Cr}$ & 0.923 & 0.872 & -0.955 & 0.899 & 1.000 & & & \\
\hline $\mathrm{Fe}$ & 0.399 & 0.289 & -0.894 & 0.951 & 0.721 & 1.000 & & \\
\hline $\mathrm{Mn}$ & -0.703 & -0.615 & 0.995 & -0.998 & -0.922 & -0.933 & 1.000 & \\
\hline $\mathrm{As}$ & -0.285 & -0.395 & -0.396 & 0.530 & 0.105 & 0.765 & -0.481 & 1.000 \\
\hline
\end{tabular}

Spinach: The concentration of all the metal studied in all sites were found to have high metals in spinach but others show lower values. The mean concentration of spinach was $\mathrm{Pb}(0.46 \pm 0.04) \mathrm{Cu}(0.06 \pm 0.01), \mathrm{Cr}(0.014 \pm 0.01)$,

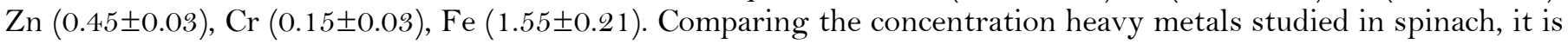
found that values obtained for $\mathrm{Pb}$ are lower than the findings of $2.9 \pm 1.2 \mathrm{mg} / \mathrm{Kg} 1.50 \pm 0.1 \mathrm{mg} / \mathrm{Kg}, 15.1 \mathrm{mg} / \mathrm{Kg} 2.78$ $\mathrm{mg} / \mathrm{Kg}, 3.31 \mathrm{mg} / \mathrm{Kg}[26],[32],[56],[64],[65]$. The concentration of $\mathrm{Cr}$ and $\mathrm{Cd}$ in agricultural soil irrigated with contaminated river water are far higher than the value reported in this work $[4],[27],[39],[66]$.

Comparing with the prescribed standards it is found that $\mathrm{Pb}, \mathrm{Cr}, \mathrm{As}$, Mn and $\mathrm{Cd}$ content in spinach have crossed safe limit $[24],[30]$. However, the major sources of vegetable contamination with heavy metals might be due to the waste water irrigation, solid waste disposal, sludge applications, vehicular exhaust. Excessive accumulation of heavy metals in agricultural soils through the use of agrochemicals and by other sources may lead to elevated heavy metal up-take by vegetables and thus affect food quality and safety [66]. Statistically heavy metals content in spinach in shows significant $(\mathrm{p}<0.05)$. $\mathrm{Pb}$ is positively correlated with $\mathrm{Cr}$ and negatively correlated with Mn and As. Wastewater induced heavy metals enrichment in spinach was also studied [4],[39]. The variations in heavy metal concentrations in vegetables of the same site may be ascribed to the differences in their morphology and physiology for heavy metal uptake, exclusion, accumulation and retention [7]. It is worthy of note that low concentrations of $\mathrm{Fe}$ in the vegetable samples relative to its abundant availability in the soils, can be attributed to; low absorption of $\mathrm{Fe}$ by the tissues of the vegetable samples, possible leaching of $\mathrm{Fe}$ from the soil surface and runoff during rainfall.

Table-9. Pearson's correlation coefficient matrix (Mean) concentration of heavy metals in spinach.

\begin{tabular}{c|c|c|c|c|c|c|c|c}
\multicolumn{6}{c}{ Table-9. Pearson's correlation coefficient matrix (Mean) concentration of heavy metals in spinach. } \\
\hline & $\mathbf{P b}$ & $\mathbf{C u}$ & $\mathbf{C d}$ & $\mathbf{Z n}$ & $\mathbf{C r}$ & $\mathbf{F e}$ & $\mathbf{M n}$ & $\mathbf{A s}$ \\
\hline $\mathrm{Pb}$ & 1.000 & & & & & & & \\
\hline $\mathrm{Cu}$ & -0.202 & 1.000 & & & & & & \\
\hline $\mathrm{Cd}$ & 0.597 & -0.906 & 1.000 & & & & & \\
\hline $\mathrm{Zn}$ & -0.771 & 0.780 & -0.971 & 1.000 & & & & \\
\hline $\mathrm{Cr}$ & 0.988 & -0.182 & 0.581 & -0.758 & 1.000 & & & \\
\hline $\mathrm{Fe}$ & 0.807 & -0.741 & 0.955 & -0.998 & 0.795 & 1.000 & & \\
\hline $\mathrm{Mn}$ & -0.796 & -0.431 & 0.009 & 0.229 & -0.809 & -0.286 & 1.000 & \\
\hline $\mathrm{As}$ & -0.882 & -0.283 & -0.149 & 0.380 & -0.891 & -0.434 & 0.987 & 1.000 \\
\hline
\end{tabular}

\subsection{Conclusion}

From the present study it is noted that tin mining pond water irrigation practice is not suitable for cultivating edible vegetables especially those that are consumed regularly. Because excess heavy metals are considered as toxic elements due to accumulation in the biological systems and subsequently interfere in metabolic activity of organ specific. In this study the vegetables cultivated with this water are not safe for consumption. So, emphasis should be made on the use of good quality irrigation water for the cultivation of vegetables which have less accumulation potential.

\section{References}

[1] A. Tsafe, L. Hassan, D. Sahabi, Y. Alhassan, and B. Bala, "Evaluation of heavy metals uptake and risk assessment of vegetables grown in Yargalma of Northern Nigeria," Journal of Basic and Applied Scientific Research, vol. 2, pp. 6708-6714, 2012.

[2] D. Nukpezah, F. A. Rahman, and S. Koranteng, "The impact of small scale mining on irrigation water quality in Asante Akim Central Municipality of Ghana," West African Journal of Applied Ecology, vol. 25, pp. 49-67, 2017.

[3] S. A. Kabir, M. S. Hassan, M. A. Abbas, and A. M. Kura, "Assessment of heavy metals contamination of soil and water around abandoned Pb-Zn mines in Yelu, Alkaleri Local Government Area of Bauchi State, Nigeria," International Research Journal of Public and Environmental Health, vol. 4, pp. 72-77, 2017.

[4] M. Arora, B. Kiran, S. Rani, A. Rani, B. Kaur, and N. Mittal, "Heavy metal accumulation in vegetables irrigated with water from different sources," Food Chemistry, vol. 111, pp. 811-815, 2008. Available at: https://doi.org/10.1016/j.foodchem.2008.04.049.

[5] A. Singh, R. K. Sharma, M. Agrawal, and F. M. Marshall, "Risk assessment of heavy metal toxicity through contaminated vegetables from waste water irrigated area of Varanasi, India," Tropical Ecology, vol. 51, pp. 375-387, 2010.

[6] A. Heshmati, "Evaluation of heavy metals contamination of unrefined and refined table salt," International Journal of Research Studies in Biosciences, vol. 2, pp. $21-24,2014$.

[7] M. Jaishankar, T. Tseten, N. Anbalagan, B. B. Mathew, and K. N. Beeregowda, "Toxicity, mechanism and health effects of some heavy metals," Interdisciplinary Toxicology, vol. 7, pp. 60-72, 2014. Available at: https://doi.org/10.2478/intox-2014-0009.

[8] A. O. Lawal and A. A. Audu, "Analysis of heavy metals found in vegetables from some cultivated irrigated gardens in the Kano metropolis, Nigeria," Journal of Environmental Chemistry and Ecotoxicology, vol. 3, pp. 142-148, 2011.

[9] M. Shagal, H. Maina, R. Donatus, and K. Tadzabia, "Bioaccumulation of trace metals concentration in some vegetables grown near refuse and effluent dumpsites along Rumude-Doubeli bye-pass in Yola North, Adamawa State," Global Advanced Research Journal of Environmental Science and Toxicology, vol. 1, pp. 018-022, 2012.

[10] S. Mohammed, A. Abdurrahman, and M. Attahiru, "Proximate analysis and total lycopene content of some tomato cultivars obtained from Kano State, Nigeria," Chem Search Journal, vol. 8, pp. 64-69, 2017. 
[11] S. Okewole, L. Oyekunle, O. Akande, T. Adebisi, and T. Olubode, "Nutritional compositions of selected green leafy vegetables in Oyo State, Nigeria," Asian Journal of Applied Chemistry Research, vol. 1, pp. 1-7, 2018. Available at: https://doi.org/10.9734/ajacr/2018/v1i19605.

[12] K. Ajewole, "Analysis of the nutritive elements in some Nigerian leafy vegetables," in Proceedings 23rd Annual NIFST Conference, Abuja, 1999, pp. 25-27.

[13] M. K. Türkdoğan, F. Kilicel, K. Kara, I. Tuncer, and I. Uygan, "Heavy metals in soil, vegetables and fruits in the endemic upper gastrointestinal cancer region of Turkey," Environmental Toxicology and Pharmacology, vol. 13, pp. 175-179, 2003. Available at: https://doi.org/10.1016/s1382-6689(02)00156-4.

[14] M. A. S. Van Duyn and E. Pivonka, "Overview of the health benefits of fruit and vegetable consumption for the dietetics professional: Selected literature," Journal of the American Dietetic Association, vol. 100, pp. 1511-1521, 2000.

[15] A. K. Ghosh, M. Bhatt, and H. Agrawal, "Effect of long-term application of treated sewage water on heavy metal accumulation in vegetables grown in Northern India," Environmental Monitoring and Sssessment, vol. 184, pp. 1025-1036, 2012. Available at: https://doi.org/10.1007/s10661-011-2018-6.

[16] G. M. Mafuyai, I. S. Eneji, and R. Sha'Ato, "Concentration of heavy metals in respirable dust in Jos metropolitan area, Nigeria," Open Journal of Air Pollution, vol. 3, pp. 10-19, 2014. Available at: https://doi.org/10.4236/ojap.2014.31002.

[17] S. Khan, S. Rehman, A. Z. Khan, M. A. Khan, and M. T. Shah, "Soil and vegetables enrichment with heavy metals from geological sources in Gilgit, northern Pakistan," Ecotoxicology and Environmental Safety, vol. 73, pp. 1820-1827, 2010. Available at: https://doi.org/10.1016/j.ecoenv.2010.08.016.

[18] Y.-J. Cui, Y.-G. Zhu, R.-H. Zhai, D.-Y. Chen, Y.-Z. Huang, Y. Qiu, and J.-Z. Liang, "Transfer of metals from soil to vegetables in an area near a smelter in Nanning, China," Environment International, vol. 30, pp. 785-791, 2004. Available at: https://doi.org/10.1016/j.envint.2004.01.003.

[19] F. K. Zengin and O. Munzuroglu, "Toxic effects of cadmium $(\mathrm{Cd}++)$ on metabolism of sunflower (Helianthus annuus L.) seedlings," Acta Agriculturae Scandinavica Section B-Soil and Plant Science, vol. 56, pp. 224-229, 2006. Available at: https://doi.org/10.1080/0906471051003087.

[20] J. O. Nriagu, "Lead orthophosphates-IV Formation and stability in the environment," Geochimica et Cosmochimica Acta, vol. 38, pp. 887-898, 1974. Available at: https://doi.org/10.1016/0016-7037(74)90062-3.

[21] G. M. Mafuyai, N. M. Kamoh, N. S. Kangpe, S. M. Ayuba, and I. S. Eneji, "Heavy metals contamination in road side dust along major traffic roads in Jos metropolitan Area Nigeria," European Journal of Earth and Environment, vol. 2, pp. 39-42, 2015.

[22] Z.-Y. Hseu, Z.-S. Chen, C.-C. Tsai, C.-C. Tsui, S.-F. Cheng, C.-L. Liu, and H.-T. Lin, "Digestion methods for total heavy metals in sediments and soils," Water, Air, and Soil Pollution, vol. 141, pp. 189-205, 2002.

[23] R. Sutherland, "Bed sediment-associated trace metals in an urban stream, Oahu, Hawaii," Environmental Geology, vol. 39, pp. 611627, 2000. Available at: https://doi.org/10.1007/s002540050473.

[24] WHO/FAO, "Joint FAO/WHO food standard programme codex alimentarius commission 13th session," Report of the Thirty Eight Session of the Codex Committee on Food, 2007.

[25] V. Daniel, E. Chudusu, J. Chup, and N. Pius, "Variations of heavy metals in agricultural soils irrigated with tin water in Heipang District of Barkin Ladi, Plateau State, Nigeria," International Journal of Science and Technology, vol. 3, pp. 674-683, 2014.

[26] A. Mahmood and R. N. Malik, "Human health risk assessment of heavy metals via consumption of contaminated vegetables collected from different irrigation sources in Lahore, Pakistan," Arabian Journal of Chemistry, vol. 7, pp. 91-99, 2014. Available at: https://doi.org/10.1016/j.arabjc.2013.07.002.

[27] A. Ratul, M. Hassan, M. Uddin, M. Sultana, M. Akbor, and M. Ahsan, "Potential health risk of heavy metals accumulation in vegetables irrigated with polluted river water," International Food Research Journal, vol. 25, pp. 329-338, 2018.

[28] I. Lente, B. Keraita, P. Drechsel, J. Ofosu-Anim, and A. K. Brimah, "Risk assessment of heavy-metal contamination on vegetables grown in long-term wastewater irrigated urban farming sites in Accra, Ghana," Water Quality, Exposure and Health, vol. 4, pp. 179186, 2012. Available at: https://doi.org/10.1007/s12403-012-0077-8.

[29] M. U. Henry, R. A. Ogenyi, U. I. Henry, and O. Dogun, "Assessment of heavy metal concentration in water, soil and cegetable in ex-mining pond, Jos South L.G.A Plateau State, Nigeria," International Journal of Scientific and Research Publications, vol. 8, pp. 840 845, 2018. Available at: https://doi.org/10.29322/ijsrp.8.8.2018.p80107.

[30] European Union (EU), "Heavy metals in wastes, European commission on environment." Available: http://ec.europa.eu/environment/waste/studies/pdf/heavymetalsreport.pdf, 2002.

[31] USEPA, Risk-based concentration table. Washington, DC: United State Environmental Protection Agency, 2010.

[32] S. Gupta, S. Satpati, S. Nayek, and D. Garai, "Effect of wastewater irrigation on vegetables in relation to bioaccumulation of heavy metals and biochemical changes," Environmental Monitoring and Assessment, vol. 165, pp. 169-177, 2010. Available at: https://doi.org/10.1007/s10661-009-0936-3.

[33] T. Takamatsu, H. Aoki, and T. Yoshida, "Determination of arsenate, arsenite, monomethylarsonate, and dimethylarsinate in soil polluted with arsenic," Soil Science, vol. 133, pp. 239-246, 1982. Available at: https://doi.org/10.1097/00010694-198204000-00007. W. J. Sanok, J. G. Ebel Jr, K. L. Manzell, W. H. Gutenmann, and D. J. Lisk, "Residues of arsenic and lead in potato soils on Long Island," Chemosphere, vol. 30, pp. 803-806, 1995. Available at: https://doi.org/10.1016/0045-6535(94)00410-v. FAO, Water quality for agriculture. Paper No. 29 (Rev.1). Rome: UNESCO, Publication, 1985.

[36] G. Kisku, S. Barman, and S. Bhargava, "Contamination of soil and plants with potentially toxic elements irrigated with mixed industrial effluent and its impact on the environment," Water, Air, and Soil Pollution, vol. 120, pp. 121-137, 2000.

[37] R.-L. Zheng, H.-F. Li, R.-F. Jiang, and F.-S. Zhang, "Cadmium accumulation in the edible parts of different cultivars of radish, raphanus sativus L., and carrot, Daucus carota var. sativa, grown in a Cd-contaminated soil," Bulletin of Environmental Contamination and Toxicology, vol. 81, pp. 75-79, 2008. Available at: https://doi.org/10.1007/s00 128-008-9410-0.

[38] J. Abah, F. Abdurahaman, N. Ndahi, and V. Ogugbuaja, "Effects of inorganic fertilizers and herbicides on levels of some heavy metals in soils and grains of rice grown in selected areas of Benue State, Nigeria," International Journal of Applied Research and Technology, vol. 1, pp. 160-166, 2012.

[39] A. G. Kachenko and B. Singh, "Heavy metals contamination in vegetables grown in urban and metal smelter contaminated sites in Australia," Water, Air, and Soil Pollution, vol. 169, pp. 101-123, 2006. Available at: https://doi.org/10.1007/s11270-006-2027-1.

[40] A. Chopra and C. Pathak, "Bioaccumulation and translocation efficiency of heavy metals in vegetables grown on long-term wastewater irrigated soil near Bindal River, Dehradun," Agricultural Research, vol. 1, pp. 157-164, 2012. Available at: https://doi.org/10.1007/s40003-012-0016-8.

[41] T. F. Duressa and S. Leta, "Determination of levels of as, $\mathrm{Cd}, \mathrm{Cr}, \mathrm{Hg}$ and $\mathrm{Pb}$ in soils and some vegetables taken from river mojo water irrigated farmland at Koka Village, Oromia State, East Ethiopia," International Journal of Sciences: Basic and Applied Research, vol. 21 , pp. 352-372, 2015.

[42] H. M. Naser, N. U. Mahmud, S. Sultana, R. Gomes, and M. Rahman, "Trace elements content in vegetables grown in industrially polluted and non-polluted areas," Bangladesh Journal of Agricultural Research, vol. 37, pp. 515-527, 2012. Available at: https://doi.org/10.3329/bjar.v37i3.12128.

[43] A. Muamar, A. Zouahri, M. Tijane, A. El Housni, Z. Mennane, H. Yachou, and M. Bouksaim, "Evaluation of heavy metals pollution in groundwater, soil and some vegetables irrigated with wastewater in the Skhirat region "Morocco"," Journal of Materials and Environmental Science, vol. 5, pp. 961-966, 2014.

[44] L. T. Bambara, K. Kabore, M. Derra, M. Zoungrana, F. Zougmoré, and O. Cisse, "Assessment of heavy metals in irrigation water and vegetables in selected farms at Loumbila and Paspanga, Burkina Faso," IOSR Journal of Environmental Science, vol. 9, pp. 2319$2399,2015$.

[45] M. B. Mahmood, "Estimation the levels of some heavy metals in the soil and vegetables irrigated with wells water in some agriculture fields at Al-Dora district-Baghdad," Iraqi Journal of Science, vol. 57, pp. 1918-1925, 2016. 
[46] O. E. Orisakwe, E. A. Dagur, H. O. C. Mbagwu, and N. A. Udowelle, "Lead levels in vegetables from artisanal mining sites of Dilimi River, Bukuru and Barkin Ladi north central Nigeria: Cancer and non-cancer risk assessment," Asian Pacific Journal of Cancer Prevention, vol. 18, pp. 621-627, 2017.

[47] P. E. Jayadev, "Assessment of heavy metals uptake in leafy vegetables grown on long term wastewater irrigated soil across Vrishabhavathi River, Bangalore, Karnataka," IOSR Journal of Environmental Science, Toxicology and Food Technology, vol. 7, pp. 5255, 2013. Available at: https://doi.org/10.9790/2402-0765255.

[48] C. Saglam, "Heavy metal accumulation in the edible parts of some cultivated plants and media samples from a volcanic region in Southern Turkey," Ekoloji, vol. 22, pp. 1-8, 2013. Available at: https://doi.org/10.5053/ekoloji.2013.861.

[49] R. K. Sharma and M. Agrawal, "Single and combined effects of cadmium and zinc on carrots: Uptake and bioaccumulation," Journal of Plant Nutrition, vol. 29, pp. 1791-1804, 2006. Available at: https://doi.org/10.1080/01904160600899246.

[50] FAO/WHO, Joint FAO/WHO food standards programme codex committee on contaminants in foods; fifth session. Expert Committee on Food Additives (JECFA). Switzerland: WHO Press Geneva, 2011.

[51] L. Shibao, W. L. Jianhua, and P. Liang, "Study on the Effects of irrigation with reclaimed water on the content and distribution of heavy metals in soil," International Journal of Environmental. Research and Public Health, vol. 13, pp. 298-308, 2016. Available at: https://doi.org/10.3390/ijerph13030298.

[52] R. Auta, S. James, T. Auta, and E. Sofa, "Nutritive value and phytochemical composition of processed Solanum incanum (Bitter garden egg)," Science World Journal, vol. 6, pp. 5-6, 2011.

[53] D. Adotey, Y. Serfor-Armah, J. Fianko, and P. Yeboah, "Essential elements content in core vegetables grown and consumed in Ghana by instrumental neutron activation analysis," African Journal of Food Science, vol. 3, pp. 243-249, 2009.

[54] O. J. Dorcas, N. E. Joseph, and J. S. Sunday, "Determination of the contamination levels of cadmium, lead, arsenic and mercury in the vegetables from old mining site of jos plateau, Nigeria," International Journal of Interdisciplinary Research and Innovations, vol. 4, pp. $40-44,2016$.

[55] Y. N. Jolly, S. Akter, J. Kabir, and A. Islam, "Health risk assessment of heavy metals via dietary intake of vegetables collected from an area selected for introducing a nuclear power plant," Research Journal of Physical and Applied Sciences, vol. 2, pp. 43-51, 2013a.

[56] A. Q. Amina, K. Qudsia, B. Ruqia, and Y. Balal, "Accessing potential bioaccumulation of heavy metals in selective vegetables from Gujranwala district," Pakistan Journal of Earth and Environmental Sciences, vol. 5, pp. 58-70, 2015.

[57] S. Sinha, A. Gupta, K. Bhatt, K. Pandey, U. Rai, and K. Singh, "Distribution of metals in the edible plants grown at Jajmau, Kanpur (India) receiving treated tannery wastewater: relation with physico-chemical properties of the soil," Environmental Monitoring and Assessment, vol. 115, pp. 1-22, 2006. Available at: https://doi.org/10.1007/s 10661-006-5036-z.

[58] G. Benti, "Assessment of heavy metals in vegetables irrigated with Awashi River in selected farms around Adama town, Ethiopia," African Journal of Environmental Science and Technology, vol. 8, pp. 428-434, 2014. Available at: https://doi.org/10.5897/ajest2014.1732.

[59] FAO/WHO, Evaluation of certain contaminants in food: Seventy-second report of the Joint FAO/WHO expert committee on food additives (JECFA). Switzerland: WHO Press Geneva, 2010.

[60] A. Abdul-Razak, A. B. Asiedu, R. E. M. Entsua-Mensah, and K. A. A. DeGraft-Johnson, "Assessment of the water quality of the Oti River in Ghana," West African Journal of Applied Ecology, vol. 15, pp. 1-20, 2009.

[61] T. J. Srinivasan and R. V. Reddy, "Wastewater irrigation in India: An analyaisof its heath impact," presented at the A Conference Paper of INSEE, Centre for Economic and Social Studies, Nizamiah Observatory Campus, Begumpet, Hyderabad, 2009.

[62] B. W. Tukura, A. C. Etonihu, I. A. Ambo, and A. Iboro, "Accumulation of heavy metals in vegetables grown on farmlands irrigated with treated sewage water," FUTN Trends in Science and Technology Journal, vol. 1, pp. 168-172, 2016.

[63] S. Roy and S. Gupta, "Effect of wastewater irrigation on soil and some selected vegetables grown in Asansol, West Bengal," International Journal of Environmental Sciences, vol. 6, pp. 894-904, 2016.

[64] K. Sadhu, K. Adhikari, and A. Gangopadhyay, "Assessment of heavy metal contamination of soils in and around open cast mines of Raniganj Area, India," International Journal of Environmental Engineering Research, vol. 1, pp. 77-85, 2015.

[65] A. Kumar and V. K. Seema, "Human health risk of heavy metals in vegetables grown in contaminated soil irrigated with sewage water," American Journal of Food Science and Nutrition, vol. 4, pp. 23-35, 2017.

[66] M. Muchuweti, J. Birkett, E. Chinyanga, R. Zvauya, M. D. Scrimshaw, and J. Lester, "Heavy metal content of vegetables irrigated with mixtures of wastewater and sewage sludge in Zimbabwe: Implications for human health," Agriculture, Ecosystems $\mathbb{E}^{\circ}$ Environment, vol. 112, pp. 41-48, 2006. Available at: https://doi.org/10.1016/j.agee.2005.04.028. 